\title{
The Microbiological Basis of Human Superorganism Freedom
}

\author{
Rodney R Dietert* \\ Department of Microbiology and Immunology, Cornell University, USA
}

*Corresponding author: Rodney R Dietert, Professor Emeritus of Immunotoxicology, Cornell University, USA.

To Cite This Article: Rodney R Dietert. The Microbiological Basis of Human Superorganism Freedom. Am J Biomed Sci \& Res. 2021 - 13(6). AJBSR.MS.ID.001933. DOI: 10.34297/AJBSR.2021.13.001933.

Received: 眥 August 05, 2021; Published: 眥 August 17, 2021

\begin{abstract}
This opinion article looks at the relationship between human biological make-up, (e.g., the biology, microbiology, genes, and human genetics), and the human condition on earth looking across two centuries. For the mid-20th century, I examine the work of the great Ukrainian-American geneticist and evolutional biologist, Theodosius Dobzhansky, with an emphasis on three key aspects of his life and career

1. His landmark theorems on genetic variability and adaptability,

2. His science- driven vision of human nature, why humans are born free and what we must do to remain free, and finally,

3. Dobzhansky's decades long personal struggle to call out non-science masquerading as science-driven policy (the Lysenko debacle).

Trofim Lysenko's disastrous agronomy program based on anti-genetics and non-science was heralded by political leaders and media alike, dominated food production in two Communist countries, resulted in horrific famine and mass starvation, and was allowed to continue across decades. Dobzhansky's individual opposition to this misuse of science that created human suffering and death was juxtaposed to the virtual silence of U.S. major genetics organizations.
\end{abstract}

Five rules for having and keeping freedom are presented from Dobzhansky's 1956 human freedom treatise. Now in the 21st century, there are interesting parallels to be made. Dobzhansky's genetics are updated to include the microbiome and the reality that we are by several measures, mainly microbial taking form as a human superorganism/holobiont. With earth being a microbial planet and humans representing a microcosm of that life, our place on earth as envisioned by Dobzhansky is even more solidified. Finally, I examine the prolonged microbiome-destroying, immune-altering public health mandates instituted for the SARS-CoV-2 pandemic that increasingly impinge upon human freedoms all in the name of science. It is useful to ask: What would Dobzhansky have to say about genes and human freedom today?

Keywords: Dobzhansky, Microbiome, Superorganism, Holobiont, Pathobiont, Noncommunicable diseases, Phylosymbiosis, Microimmunosome, Lysenkoism, SARS-CoV-2, Pandemic, Mandates, Freedom

Abbreviations: NCDs: Noncommunicable diseases and conditions; Staph A: Staphylococcus aureus; WHO: World Health Organization; Microimmunosome: microbiome-barrier-immune system systems biology unit

\section{Introduction}

Theodosius Dobzhansky (b. 1900-d. 1975) was a celebrated Ukrainian-American geneticist and evolutionary biologist who is credited with bringing together a remarkably diverse body of genetic, evolutionary, and cultural knowledge to form what became known as the Synthetic Theory of Evolution, also known as the Modern Synthesis of Evolutionary Theory [1]. Among numerous accomplishments (which included bringing genetics to much of Latin America [2], Dobzhansky formulated paradigm-shifting science through what became known as the "balance hypothesis." This hypothesis stresses that lots of genetic variation within populations is a wonderful thing as it provides equal opportunity for success. It is the foundation of how earth organisms, especially humans, naturally operate. These views both reflected his research findings and helped to mold his world view.

To both honor Dobzansky's historical work and to show its usefulness in today's context, this opinion article is divided into two 
parts. The first part highlights Dobzhansky's breakthrough science and broader pursuit of the societal meaning of humans on earth. It will highlight Dobzhansky's history, background, and battles, which are little known today. Knowledge of Dobzhanky's struggles to preserve the integrity of science and human freedom are being lost. Yet, there are lessons in his experiences that we need more than ever. Much of Dobzhansky's career included personal battles against the anti-science, anti-genetics worldview and practices embraced by Marxism and Communism that threatened both science and human freedom. These battles and his life experiences in the new Soviet Union provided the context for his genetic-cultural-societal 1956 book, "The Biological Basis of Human Freedom" [3]. This book includes not only Dobzhansky's arguments that genetically as humans we deserve to be free, as evidenced by the title, but also his guidance concerning what we must do to keep our freedom.

The second part of this article brings Dobzhansky's foundational mid-20th century struggle into the $21^{\text {st }}$ century. Here, it can help guide us as we face our own version of the "politics of science" and a new form of "anti-science" that restricts human freedoms. In the 21st century there are no longer "humans" as we used to think of ourselves. There is the human superorganism. We now know that:

1. Earth is a microbial planet.

2. Most complex organisms on earth, including humans, are superorganisms/holobionts.

3. Humans may be the symbiotic pinnacle, the richest source of symbiotic microbial life among all of earth's complex organisms and

4. Few complex organisms on earth can thrive or even survive without their microbial co-partners. Yet, we are on a collision course with ourselves in pursing an anti-microbe global attack.

In a nutshell, for all of life on earth to continue, earth microbes including our copartners must be protected. Microbial health is our health. Our prime directive should be to protect and nurture the human microbiome. The human microbiome contains greater than $99 \%$ of all our genes [4]. When microbial life is threatened, humans become untethered from earth, our genes are stripped away, our metabolic capacities are diminished, and the human body that has relied on microbes for millenia becomes damaged and loses its functions (immunological, neurological, gastrointestinal, reproductive). We are challenged to survive. The life's lessons of Theodosius Dobzhansky, particularly when updated for superorganisms and the era of the microbiome, is timely for the present and any future pandemics. There are disturbing parallels between the public health pandemic mandates of today and the freedom gutting, anti-genetics campaign of the past century. As will be described, the Stalin-Lysenko 20th century anti-genetics campaign led to untold human suffering and massacres. That antigenetics campaign has been replaced by today's attack on microbes and fear of everything microbial. Almost inconceivably, a single pathobiont is today's justification for loss of human freedom. It is time for a Dobzhansky redux to save the human superorganism.

\section{Dobzhansky: Right Time, Right Place}

Dobzhansky reached adulthood just as Russia took Ukraine into the Soviet Union. This set a course affecting the remainder of his life and career. After marrying a fellow geneticist in 1924 and studying genetics under a Russian scientist in Kiev then in St. Petersburg, Dobzhansky had the opportunity to leave the Communist sphere of the recently formed Soviet Union, never to return. In fact, after Dobzhansky left, the Soviet Union sequestered his early records and work for decades preventing a glimpse of his earliest work [5]. In 1927, Dobzhansky received a fellowship from the Rockefeller Foundation's International Education Board to come to New York City to study in the Drosophila genetics lab of Thomas Hunt Morgan at Columbia University. When Morgan moved his laboratory to Cal Tech in 1928, Dobzhansky went with him $[2,6]$ eventually becoming a faculty member at Cal Tech, Columbia University, The Rockefeller Institute, and the University of California at Davis.

\section{Dobzhansky's Scientific Legacy}

For the $20^{\text {th }}$ century, Dobzhansky provided a clear path reconciling the ideas of Gregor Mendel and Charles Darwin by bringing in newer ideas from a whole host of biological disciplines. He did so while training more than 30 graduate students and serving as a professor at Cal Tech, Columbia University, and The Rockefeller Institute [1]. Importantly, Dobzhansky showed that it was necessary to adapt prior core scientific concepts to new discoveries as a way to discern the place and role of humans on earth. Along with his colleague, Herman Joseph Muller, one of Dobzhansky's major findings dealt with hybrid incompatibilities and speciation [7]. Called the Dobzhansky-Muller Model, it led to our understanding that when populations diverge to such an extent that mating produces hybrids that have chromosomally-derived incompatibility, the offspring will either die or be sterile. The effect is that a new species is created. Hence, Dobzhansky provided an important genetic explanation for Darwin's observations of species in the $19^{\text {th }}$ century.

Eventually, Dobzhansky separated conceptually from Muller and formed what became known as the "balance hypothesis." His research work in the tropics (Brazil) and studies of tropical niche diversity led him to believe that it was very advantageous to have lots of genetic variation within a population. This was because today's most promising genotype in terms of "fitness" could end up in the dustbin of tomorrow's changing conditions on earth. Dobzhansky relished genetic diversity and what has been termed 
by some authors as the "equality of opportunity" [8]. While Dobzhansky worked primarily on the genetics and evolution of fruit flies. His stated ultimate goal was to better understand humans and our place in the universe [8]. It is from the vantage point as a scientific leader in 20th century understanding of genetics and evolutionary biology that in 1956 Dobzhansky published his work "The Biological Basis of Human Freedom."

\section{Dobzhansky Rejects Communism and its Anti-Genetic Lysenkoism-Fueled, Human Massacre}

Dobzhansky's initial time in the US was via a Rockefeller Foundation fellowship to work with Morgan. As the situation in his Soviet homeland continued to deteriorate both in terms of loss of freedoms and politics of permittable science, his temporary stay in the U.S. became permanent. Dobzhansky was deemed a non-person in his homeland. Rather than genetics coming to the forefront under Stalin, the opposite happened. A disbeliever in genetics and breeding, Trofim Lysenko led Soviet agriculture into what, in retrospect, seems like a ridiculous science-devoid program to appropriately "educate" Soviet crops. Annual crop failures and mass starvation ensued [9]. Decades later after Stalin's death and Lysenko's star had faded, Communist China adopted his agricultural plans to the same end [9].

As described by Qury [10], Lysenko was a perfect tool for first the Soviet Union and then Communist China's population relocation and massive population reduction initiatives. Importantly, it required two elements:

1. Lysenko overtly lying about his experimental results so his protocols could be implemented first nationally and then internationally to China.

2. State News that covered up for Lysenko and his failed outcomes. Importantly, there is a lesson to be learned from Lysenko's disastrous, anti-science agricultural policies, which were aggressively promoted by political leaders (to the extent that they silenced and sometimes killed the voices of reason). The lesson is that citizens have a right to see the scientific details leading to science-based policy changes. Soviet and Chinese citizens were not so lucky during much of the $20^{\text {th }}$ century.

The culmination of the anti-genetic, anti-science movement in the Soviet Union came at the 1948 Meeting of the Lenin All-Union Academy of Agricultural Sciences where Lysenko and Stalin finally vanquished genetics [11]. Dobzhansky and a handful of prominent geneticists had been railing against the Communist anti-genetic movement and waging personal battles to that effect. However, as described by Sekya [12], the fledgling Genetics Society of America utterly failed to mount a clear organizational effort and statement against the very political movement (Soviet Lysenkoism and Communism) that wanted to destroy it. Scientific freedom was in jeopardy. Dobzhansky and his closest genetics colleagues would resist this, but largely on their own. It is from these experiences that Dobzhansky prepared his book "The Biological Basis of Human Freedom." Benjamin Franklin, a scholar and prominent founder of the American republic, had a reputed exchange when asked by a woman what kind of government they had created. His reply was "a republic.... if you can keep it." In a similar vein, Dobzhansky's message is that humans are inherently free by our nature, if we can keep it.

\section{Five Rules from Dobzhansky for Having and Keeping Human Freedom}

In the final section of Dobzhansky's 1956 book [3], he provided five rules that flow from human genetics, evolution, and culture and are critical for having and keeping human freedom. They are listed as follows:

\section{You have the right to choose freely between ideas and acts}

As Dobzhansky states "The ability of man to choose freely between ideas and acts is one of the fundamental characteristics of human evolution. Perhaps freedom is even the most important of all the specifically human attributes. Human freedom is wider than "necessity comprehended," which is the only kind of freedom recognized by Marxists. Man has freedom to defy necessity, at least in his imagination. Ethics emanate from freedom and are unthinkable without freedom" [3, see page 134]

\section{Freedom of choice trumps unthinking (automatic) conformity}

As Dobzhansky states "There is no automatism that will carry him upward without choice or effort and there is no trend solely in the right direction. Evolution has no purpose; man must supply this for himself" [3, see page 134].

\section{Do not willingly isolate yourself. We are made for society}

As Dobzhansky says "Interpersonal relations constitute the most important aspect of human environment" [3, see page 124]. (Note: Dobzhansky indicates that this original idea was derived from C. D. Leake.)

\section{Do not forsake your core human connections}

Families and communities are the significant unit. Dobzhansky states "Tribes are units of natural selection" [3, see page 126-127].

\section{Question everything}

The minute you are told not to do so, be very suspicious. As Dobzhansky states "Despite any exhortations to the contrary, man 
will not permanently deny himself the right to question the wisdom of anything" [3, see page 129].

\section{Updating Dobzhansky's Genetics for the Microbiome Revolution}

Earth is a microbial planet [13] and across the human microbiomes (the bacteria, viruses, fungi, archeae and their genes) located in various body sites, we have a very good representation of that life on earth [14]. We are a microcosm of earth's microbial life and are intrinsically linked with earth's microbes. Additionally, we are very mobile. So, we spread those microbes far and wide much like John Chapman (better known as Johnny Appleseed) who was a pioneer nurseryman distributing apple trees as he traveled across the American Midwest.

The human microbiome contributes greater than $99 \%$ of the genes for the human body [4]. As a result, if you are researching human genetics, metabolism, physiology, immunity, it is hard to overlook the microbiome. Microbial genes constitute the vast majority of "human" genetics vs. human chromosomes. For the fruit fly species Dobzhansky extensively researched Drosophila pseudoobscura, the story is a little different. In general, fruit flies have a limited diversity of gut bacteria. For Drosophila melanogaster where there is more specific analysis of the microbiome than in Dobzhansky's research species, there are between 5-20 different microbial species [15]. However, the D. pseudoobscura flies put their microbiome to good use. A recent study found that female selection of mates is dependent at least in part on males having a complete microbiome. If everything else is equal, the females prefer the older male [16].

Of course, there is a $21^{\text {st }}$ century update of the DobzhanskyMuller Model of speciation as discussed by Dietert and Dietert [17]. From the work of Seth Bordenstein (Vanderbilt University), Kevin Theis (Wayne State Medical School) and their colleagues, it is clear that speciation is not restricted to host chromosomal incompatibilities in hybrids that separate populations into new species [18]. Speciation can occur when there are microbiomeimmune incompatibilities across populations. In this case the microbial genes are just as important in the process as are the chromosomal genes of the host. So, the Dobzhansky-Muller model had to be updated to work for earth's superorganisms. New principles of biology have been identified that pertain to holobionts and hologenomes [18] including the human holobiont.

One wonders if the hidden impact of human microbiome genes could have been a part of what Dobzhansky had been perceiving as extensive human genetic variation across populations. Certainly, Dobzhansky believed that humans were well suited for life on earth. But what is known about the human microbiome now suggests that we are even more a representation of life on earth than had been imagined in the mid- $20^{\text {th }}$ century.

\section{The Microimmunosome and Phylosymbiosis}

Phylosymbiosis as described by Lim and Bordenstein [19] is when microbial communities recapitulate the phylogeny of their hosts $[20,21]$. This means that the microbiome and host become synced, and that host fitness (and wellness) depend upon this continued syncing. Deviation of the microbiome beyond the boundary tolerated by the host immune system produces incompatibilities. As discussed by Lim and Bordenstein [19], microbiome transplants across this host-tolerated barrier result in survival and fitness/health problems. Dietert [22] discusses how poor microbiome seeding and/or microbiome degradation and repopulation have potential hazards. The outcome of the host immune system encountering a microbiome that is outside of tolerable limits is holobiont breakdown via inflammation-driven noncommunicable diseases (NCDs) [22]. One can view much of human disease as being a problem with phylosymbiotic breakdown.

\section{Public Health Mandates That Ignore Fundamental Superorganism Biology and the Microbiome Revolution}

A long list of mandated human restrictions has been imposed on healthy humans for prolonged intervals during the pandemic of 2020-2021. Early-on in the pandemic response process, a multiinstitution, landmark paper was developed and published in the Proceeding of the National Academies of Sciences (PNAS) by a group of highly-prestigious microbiome, biomedical researchers [23]. This PNAS paper called out several instituted public health mandates as being inherently anti-microbiome and leading to significant destruction of an already depleted [23] human microbiome. The Finlay et al. [23] paper shows all one needs to know about the threat to human superorganism completeness, long-term health, and wellbeing. The authors suggested some modified measures that could lessen the impact of the problematic mandates. But to date, few, if any tangible steps have been taken among public health leaders to spare the microbiome. Is this the Lysenko redux that Kean (The Atlantic) and Qury (European Scientist) warned us about? In support of the effort of those scientists involved in the PNAS paper, Table 1 [24-51] provides additional information regarding several public health pandemic mandates and their impact on the microimmunosome as well as other microbiomedriven systems biology units (e.g., Gut-Immune-Brain and Gut-Bile Acids metabolism).

Some of the more common restrictions shared across countries, states, and provinces provide useful examples for discussion (as shown in Table 1). Those decisions, which were justified as based on public health and supposedly grounded in the latest risk-benefit 
science, have a problem. That problem is that the decisions run completely counter to both Dobzhansky's single-species view of 20th century human biology (despite it being 65 years old) and to $21^{\text {st }}$ century microbiology and our fundamental knowledge of the human superorganism/holobiont. It could be $20^{\text {th }}$ century science that underpins recent public health pandemic "policy" [17]. But, if so, it is certainly not providing the best scientific ideas that century had to offer [3].

\begin{tabular}{|c|c|c|c|}
\hline $\begin{array}{l}\text { Public Health-Based } \\
\text { Decision }\end{array}$ & $\begin{array}{l}\text { Targeted Factors Needed to Maintain } \\
\text { Superorganism Health }\end{array}$ & $\begin{array}{l}\text { Adverse Impact(s) on the Microimmunosome } \\
\text { and Other Systems Biology Units }\end{array}$ & Relevant References \\
\hline $\begin{array}{c}\text { Persistent, } \\
\text { Widespread Use of } \\
\text { Facial Masks }\end{array}$ & $\begin{array}{l}\text { Skin, Nasal and Oral Microbiome Balance; Mirror } \\
\text { neurons, communication, empathy, and infant } \\
\text { development; Risk of pathobiont-induced and } \\
\text { psoriatic lesions }\end{array}$ & $\begin{array}{l}\text { Degraded colonization resistance; elevated } \\
\text { risk of pathobiont infections and psoriatic } \\
\text { lesions (skin, airways, oral); risk of elevated } \\
\text { inflammation, Loss of communication and infant } \\
\text { neurodevelopment cues }\end{array}$ & [24-28] \\
\hline Isolation/Lockdown & $\begin{array}{l}\text { Pursue activities that aid microbiota diversity, } \\
\text { and physiological homeostasis, Ability to obtain } \\
\text { healthy food, pursue physical activity, have } \\
\text { meaningful human-human contact, spend time } \\
\text { in sunlight and nature, get timely treatment of } \\
\text { NCDs }\end{array}$ & $\begin{array}{l}\text { Microbiome erosion due to lack of sustaining and } \\
\text { replenishing environments and reduced human } \\
\text { contact, decrease in food security and timely } \\
\text { medical care for NCDs, potential adverse impact } \\
\text { on caregivers, and those with disabilities }\end{array}$ & {$[23,29-31]$} \\
\hline $\begin{array}{l}\text { Social Distancing/ } \\
\text { Hypersanitation }\end{array}$ & $\begin{array}{l}\text { Exchange of friendly microbes; Maintenance of } \\
\text { skin, nasal, and oral microbiomes }\end{array}$ & $\begin{array}{l}\text { Lack of exposure to friendly commensals; Over } \\
\text { sanitization and killing of skin microbiota; Nasal } \\
\text { and oral microbiomes affected by repeated } \\
\text { volatile organics exposure }\end{array}$ & {$[32,33]$} \\
\hline $\begin{array}{l}\text { Closed Parks, and } \\
\text { Beaches }\end{array}$ & $\begin{array}{l}\text { Vitamin D above minimum levels is needed for } \\
\text { both microbiome balance and effective immune } \\
\text { function, Sunlight can have an anti-allergy effect } \\
\text { in children; Exposure to soil bacteria such as } \\
\text { Mycobacterium vaccae are anti-allergic and } \\
\text { improve neurological health }\end{array}$ & $\begin{array}{l}\text { Low vitamin D is a risk factor for both risk for } \\
\text { Covid-19 infection and risk of severe disease; } \\
\text { Low sunlight increases the risk of multiple } \\
\text { sclerosis, Soil bacteria like Mycobacterium vaccae } \\
\text { have anti-allergic and anti-anxiety effects. }\end{array}$ & [34-39] \\
\hline Closed Gyms & $\begin{array}{l}\text { Exercise benefits the microbiome and } \\
\text { microbiome-related metabolism }\end{array}$ & $\begin{array}{l}\text { Sedentary lifestyle risks for microbiome } \\
\text { composition and microimmunosome function. }\end{array}$ & {$[40-43]$} \\
\hline $\begin{array}{l}\text { Restricted travel and } \\
\text { visits to family and } \\
\text { friends }\end{array}$ & $\begin{array}{l}\text { Family and community interactions are part of } \\
\text { what sustain us in challenging times. }\end{array}$ & $\begin{array}{l}\text { Mandates that impede support structures create } \\
\text { public health problems, not solutions. One } \\
\text { example is the adverse effects when family/ } \\
\text { friend caregivers are banned from postoperative } \\
\text { hospital visits }\end{array}$ & {$[44,45]$} \\
\hline $\begin{array}{l}\text { Restricted Access to } \\
\text { Seeds During Spring } \\
\text { Planting }\end{array}$ & $\begin{array}{l}\text { Foods rich in phytonutrients, free from } \\
\text { herbicides/pesticides and free from problematic } \\
\text { processing (e.g., sugar, emulsifiers) are needed to } \\
\text { support the microimmunosome }\end{array}$ & $\begin{array}{c}\text { Increased reliance on limited food sources } \\
\text { that offer mainly processed, factory-farmed } \\
\text { foodstuffs; Loss of health benefits associated } \\
\text { with outdoor gardening; Loss of food security at } \\
\text { a time of crisis. }\end{array}$ & {$[46-51]$} \\
\hline
\end{tabular}

It is careless, if not dangerous, in the $21^{\text {st }}$ century to pursue public health decisions while seemingly ignorant of the significance of the microbiome. The microbiome has a role in:

a. Organismal integrity.

b. Systems biology physiological functions.

c. Metabolic and immunologic regulation.

d. Colonization resistance against pathobionts.

e. Regulation of chronic disorders.

f. The overall health and wellbeing of humans. The path to protecting human health does not run though the destruction of the human microbiome.

\section{Masking Intentions, Aiding Pathobionts}

As illustrated in Table 1, the most significant hazard from persistent, prolonged mask wearing falls into two categories.: direct adverse impact on microbiomes and problem with gut-to-vagus nerve-to-brain neurological function. The skin, nasal and possibly oral microbiomes are impacted by the changed environment of the facial covers. In association with reduced colonization resistance in the skin, there is an increased risk of impetigo. One of the pathobionts that contributes to impetigo is Staphylococcus aureus (Staph A) [52]. Besides the fact that Staph A is often antibiotic resistant, Staph A carriage is a risk factor for the development of asthma [53]. Asthma has 36 distinct comorbidities associated with it [22]. Staph A, with its enterotoxins, combined with an elevated 
risk of asthma is not a trivial side effect. An additional problem with the prolonged mass population masking is an increased risk for psoriatic skin lesions falling into several different categories [54].

A second problem is the inability to engage the full face of other humans. Masking up and blocking the face means that mirror neuron empathy is missing, communication is incomplete, and potential anxiety is elevated over inability to discern intent [55-57]. We are forced to engage in distinctly non-human-like interactions with others we meet. This goes to the heart of suppressing precisely what Dobzhansky found is a core human trait and need: humanhuman meaningful contact.

\section{Lockdowns of the Healthy}

Lockdown of healthy individuals vs. the sick is an interesting public health choice. But it is also one that is uncommon, if not unprecedented. In looking for a precedent one example comes to mind. It is a legendary mass lockdown that was imposed on healthy humans in the name of safety and justified as necessary for the public good. That was the lockdown of all citizens of Coventry, England during the ride of Lady Godiva. Of course, the ride of legend itself was in protest to government over-reach (oppressive taxation). Fortunately, unlike the present Covid-19 lockdowns, Lady Godiva's ride was not said to have persisted for months on end. However, like today, there were severe consequences for a lack of compliance. It appears that public health experts are invoking the Lady Godiva rule both frequently and on short notice. At least as a second round of potential mass lockdowns are being seriously considered, there are some voices suggesting that "groupthink" on locking down entire populations might be a mistake [58].

\section{No Treadmill for You}

The almost immediate closure of gyms, which is part of a healthy lifestyle for many people, is an obvious negative factor in our ability to maintain overall fitness and a robust microbiome. There is little substitute for including physical activity as part of a preventative medicine plan. Not surprisingly, being cloistered and sedentary is not a physician's prescription for reducing the risk of future chronic disorders/NCDs. Note that the World Health Organization indicates that for a majority of people globally, NCDs rather than infections are the cause of death [59].

\section{Taboo Sand, Sun, and Greenspaces}

Much like the gym ban, the ban on access to beaches and parks prevents people from getting natural vitamin D via sunlight and outdoor exercise beyond their backyard. Beyond natural vitamin D exposure, sunlight has protective effects against certain immune dysfunction-associated allergies [34] and the autoimmune neurological condition, multiple sclerosis [60]. Additionally, greenspace exposure has been identified as an important factor in pain management associated with a variety of diseases and conditions [39] plus specific soil bacteria can protect against allergies as well as depression/anxiety.

\section{Alcohol/Triclosan? Up}

Social distancing while over sanitizing is a problematic combination for keeping a healthy microbiome. Frequent use of anti-bacterial solvents (alcohols or worse holdovers that might contain triclosan) does what it is supposed to do, it kills your microbes. Mahmood et al. [33] recently discussed the issue that hand sanitizers are not innocuous relative to human health. Overuse can be as much of a hazard as under use [61,62]. There is the problem that hand sanitizers are being used (and overused) with the intent to kill Covid-19 virus. But in killing bacteria both on people and in the environment (e.g., surfaces), the bacteria that grow up next are likely to have more antimicrobial resistance [63]. This means that hand sanitizers/antimicrobials you over-use today are likely to become less effective next week or next month. There is a life span for effectiveness of anti-microbials. Short term gain for long term increased pain and lethality is the actual public health formula that comes to mind.

Once the skin, etc., microbiota are killed, what happens to the depleted microbiome? Non-contact with others means that the commensal microbes you did not want killed and need back for a healthy skin, nose, and mouth are less likely to be replenished via healthy human contact. Where will they come from? Or will your microbiome remain depleted/dysbiotic? Take heart, one recent study indicates that children can readily pick up their dog's microbiota [64]. However, we know that both hospitals [65] and assisted living facilities [66] are potent sources of antibiotic resistant pathobionts. Those facilities may become the source of the microbes completing a deficient microbiome, thereby, making that microbiome even more dysbiotic.

\section{Family Visits/Travel}

SARS CoV-2 (Covid-19) restrictions included bans on travel to certain areas and on visiting high risk family members. While this could be understandable for brief intervals during the initial outbreak, prolonged blockage of the very interactions that help humans thrive is mystifying. Public health officials and politicians following their suggestions ended up prohibiting the very interactions that Dobzhansky concluded are an essential part of being human (family/community/tribe human-human contact). Their actions were dehumanizing. If risk-benefit analysis was done on the detrimental effects of prolonged human family disruption including with potential family caregivers, it was not widely disseminated among the public. Many people died alone, banned from receiving any family support. As Alejandra Victoria Capozzo (Institute of Virology and Technical Innovations, Argentina) said in her Frontiers of Public Health paper "If we lose humanity, it will be our fault. We will not be able to blame it on the virus" [44]. 


\section{Seeds of Hope}

One of the most surprising and least logical mandates (even if short lived) was a ban on selling seeds in Michigan. At the time (April 2020) [67], continued food availability was a major concern. Additionally, it was a time that spring planting would take place for those who pursued backyard or community gardening. The opportunity to work outdoors, get more sunshine, physical activity, and produce a portion of the family's food while controlling the food quality all contribute to better health. Scientists have noted that backyard and community produce production is particularly important for poorer, underserved communities such as in Detroit [49] and economically suffering urban areas of Michigan [50]. Furthermore, other cities and local governments outside the U.S. have touted urban gardening as "Seeds of Hope" in building food resiliency specifically as an answer to the Covid-19 pandemic [51].

\section{Conclusions}

Dobzhansky's research and scholarship were not only remarkable in terms of his contribution to our understanding of genetics and evolution, but also for his insights into the role of humans on earth. He posited we were biologically born to be free but needed to work to keep it. Dobzhansky was among a handful of prominent geneticists to warn about the con of non-science (Lysenkoism) touted by political leaders and media alike as the "science" that must be followed. Ratcheting forward to this century, the most significant change is in our understanding of human genetics. As human superorganisms, we are mainly microbial. Our place in the world is even more reflective of life on earth. Earth's predominant life-form (the microbes) is our predominant gene pool. But ironically, many public health mandates particularly during the SARS-CoV-2 pandemic have produced a parallel effect to what was seen with Lysenkoism. The mandated restrictions disconnect us from the very things that make us human: our commensal microbes, our human-human interactions (i.e., humanity), and our freedom.

\section{Acknowledgements}

The author thanks Janice Dietert for her editorial suggestions.

\section{Conflict of Interest}

The author declares that there is no conflict of interest.

\section{References}

1. Ayala FJ, Fitch WM (1997) Genetics and the origin of species: an introduction. Proc Natl Acad Sci U S A 94(15): 7691-7697.

2. Barahona A, Ayala FJ (2005) Theodosius Dobzhansky's Role in the Emergence and Institutionalization of Genetics in Mexico. Genetics 170(3): 981-987.

3. Dobzhansky T (1956) The Biological Basis of Human Freedom. $1^{\text {st }}$ edition. Columbia University Press. New York NY, USA.
4. Gilbert JA, Blaser MJ, Caporaso JG, Jansson JK, Lynch SV, et al. (2018) Current understanding of the human microbiome. Nat Med 24(4): 392400 .

5. Adams MB (1994) The Evolution of Theodosius Dobzhansky: Essays on His Life and Thought in Russia and America. Princeton University Press, Princeton, NJ US.

6. Miko I (2008) Thomas Hunt Morgan and sex linkage. Nature Education 1(1): 143.

7. Johnson $\mathrm{N}$ (2008) Hybrid incompatibility and speciation. Nature Education 1(1): 20.

8. De Carvalho TB (2020) Modern Evolutionary Biology and Brazilian Population Genetics: Theodosius Dobzhansky at the University of São Paulo. Perspect Sci 28 (2): 223-243.

9. Kean S (2017) The Soviet Era's Deadliest Scientist Is Regaining Popularity in Russia. The Atlantic.

10. Qury J-P (2018) European Scientist The Lysenko affair: a comeback for the Fake News that led to millions of deaths?

11. Borinskaya SA, Ermolaev AI, Kolchinsky EI (2019) Lysenkoism Against Genetics: The Meeting of the Lenin All-Union Academy of Agricultural Sciences of August 1948, Its Background, Causes, and Aftermath. Genetics 212(1): 1-12.

12. Selya R (2012) Defending Scientific Freedom and Democracy: The Genetics Society of America's Response to Lysenko. Journal of the History of Biology 45(3): 415-442.

13. (2018) Planet of the microorganisms. Nat Rev Microbiol 16: 257

14. Lurie-Weinberger MN, Gophna U (2015) Archaea in and on the Human Body: Health Implications and Future Directions. PLoS Pathogens 11(6): e1004833.

15. Ludington WB, Ja WW (2020) Drosophila as a model for the gut microbiome. PLoS Pathog 16(4): e1008398.

16. Heys C, Lizé A, Lewis Z, Price TAR (2020) Drosophila Sexual Attractiveness in Older Males Is Mediated by Their Microbiota. Microorganisms 8(2): 168.

17. Dietert RR, Dietert JM (2021) Twentieth Century Dogmas Prevent Sustainable Healthcare. Am J Biomed Sci \& Res 13(4): 409-417.

18. Bordenstein SR, Theis KR (2015) Host Biology in Light of the Microbiome: Ten Principles of Holobionts and Hologenomes. PLoS Biol 13(8): e1002226.

19. Lim SJ, Bordenstein SR (2020) An introduction to phylosymbiosis. Proc Biol Sci 287(1922): 20192900.

20. Brucker RM, Bordenstein SR (2012) Speciation by symbiosis. Trends Ecol Evol 27(8): 443-451.

21. Brucker RM, Bordenstein SR (2013) The hologenomic basis of speciation: gut bacteria cause hybrid lethality in the genus Nasonia. Science 341(6146): 667-679.

22. Dietert RR (2021) Lessons for Human Holobiont Medicine in The Era of SARS-Cov-2. Am J Biomed Sci \& Res 13(2): 152-156.

23. Finlay BB, Amato KR, Azad M, Blaser ML, Bosch TCG, et al. (2021) The hygiene hypothesis, the COVID pandemic, and consequences for the human microbiome. Proc Natl Acad Sci U S A 118(6): e2010217118.

24. Rayson H, Bonaiuto J, Ferrari P, Lynne Murray (2017) Early maternal mirroring predicts infant motor system activation during facial expression observation. Sci Rep 7: 11738. 
25. Donges U-S, Kersting A, Suslow T (2012) Women's Greater Ability to Perceive Happy Facial Emotion Automatically: Gender Differences in Affective Priming. PLoS One 7(7): e41745.

26. Giacalone S, Minuti A, Spigariolo CB, Passoni E, Nazzaro G, et al. (2020) Facial dermatoses in the general population due to wearing of personal protective masks during the COVID-19 pandemic: first observations after lockdown. Clin Exp Dermatol 46(2): 368-369.

27. Damiani G, Gironi LC, Kridin K, Pacifico A, Buja A, et al. (2021) Maskinduced Koebner phenomenon and its clinical phenotypes: A multicenter, real-life study focusing on 873 dermatological consultations during COVID-19 pandemics. Dematol Ther 34(2): e14823.

28. Wilcha RJ (2021) Does Wearing a Face Mask During the COVID-19 Pandemic Increase the Incidence of Dermatological Conditions in Health Care Workers? Narrative Literature Review. JMIR Dermatol 4(1): e22789.

29. Parajuli A, Grönroos M, Siter N, Puhakka R, Vari HK, et al. (2018) Urbanization Reduces Transfer of Diverse Environmental Microbiota Indoors. Front Microbiol 9: 84

30. Fallon N, Brown C, Twiddy H, Brian E, Frank B, et al. (2020) Adverse effects of COVID-19-related lockdown on pain, physical activity and psychological well-being in people with chronic pain. British Journal of Pain 15(3): 357-368.

31. Swainston J, Chapman B, Grunfeld EA, Derakshan N (2020) COVID-19 Lockdown and Its Adverse Impact on Psychological Health in Breast Cancer. Front Psychol 11: 2033.

32. Domingues CPF, Rebelo JS, Dionisio F, Botelho A, Nogueira T, et al. (2020) The social distancing imposed to contain COVID-19 can affect our microbiome: a double-edged sword in human health. mSphere 5: e00716-e00720.

33. Mahmood A, Eqan M, Pervez S, Alghamdi HA, Tabinda AB, et al. (2020) COVID-19 and frequent use of hand sanitizers; human health and environmental hazards by exposure pathways. Sci Total Environ 742: 140561.

34. Rueter K, Jones AP, Siafarikas A, Chivers P, Prescott SL, et al. (2021) The Influence of Sunlight Exposure and Sun Protecting Behaviours on Allergic Outcomes in Early Childhood. Int J Environ Res Public Health 18(10): 5429.

35. Conteville LC, Vicente ACP (2020) Skin exposure to sunlight: a factor modulating the human gut microbiome composition. Gut Microbes 11(5): 1135-1138.

36. Ghasemian R, Shamshirian A, Heydari K, Malekan M, Alizadeh-Navaei R, et al. (2021) The Role of Vitamin D in the Age of COVID-19: A Systematic Review and Meta-Analysis. Int J Clin Pract : e14675.

37. Ostkamp P, Salmen A, Pignolet B, Görlich, D, Andlauer TFM, et al. (2021) Sunlight exposure exerts immunomodulatory effects to reduce multiple sclerosis severity. Proc Nat Acad Sci USA 118(1): e2018457118.

38. Strygin AV, Nesmiyanov PP, Petrov VI, Tolkachev BE, Morkovin EI, et al. (2020) Mycobacterium vaccae Lysate Induces Anti-Allergic Immune Response In Vitro. Bull Exp Biol Med 170(2): 226-229.

39. Stanhope J, Breed MF, Weinstein P (2020) Exposure to greenspaces could reduce the high global burden of pain. Environ Res 187: 109641.

40. Moitinho-Silva L, Wegener M, May S, Schrinner F, Akhtar A, et al. (2021) Short-term physical exercise impacts on the human holobiont obtained by a randomised intervention study. BMC Microbiol 21(1): 162.

41. Strasser B, Wolters M, Weyh C, Krüger K, Ticinesi A (2021) The Effects of Lifestyle and Diet on Gut Microbiota Composition, Inflammation and Muscle Performance in Our Aging Society. Nutrients 13(6): 2045.
42. Divella R, DE Palma G, Tufaro A, Pelagio G, Gadaleta-Caldarola G, et al. (2021) Diet, Probiotics and Physical Activity: The Right Allies for a Healthy Microbiota. Anticancer Research 41(6): 2759-2772.

43. Simpson RJ, Boßlau TK, Weyh C, Niemiro GM, Batatinha H, et al. (2021) Exercise and Adrenergic Regulation of Immunity. Brain Behavior Immunity 591(21): 00274-00279.

44. Capozzo AV (2020) Dying Alone Due to COVID-19: Do the Needs of the Many Outweigh the Rights of the Few-or the One? Front Public Health 8: 593464.

45. Zeh RD, Santry HP, Monsour C, Sumsky AA, Bridges JFP, et al. (2020) Impact of visitor restriction rules on the postoperative experience of COVID-19 negative patients undergoing surgery. Surgery 168(5): 770776.

46. Zick CD, Smith, KR, Kowaleski-Jones L, Uno C, Merrill BJ, et al. (2013) Harvesting More Than Vegetables: The Potential Weight Control Benefits of Community Gardening. Am J Public Health 103(6): 1110-1115.

47. Brown K, Jameton A (2000) Public Health Implications of Urban Agriculture. J Public Health Pol 21(1): 20-39.

48. Chakrapani K, Balraj G, Thiyagarajan TM (2020) Urban Gardening for The Pandemic. AgroScience Today 1(1): 0017-0020.

49. Robbins J, Seibel K (2020) Temporal aspects of wellbeing in later life: Gardening among older African Americans in Detroit. Ageing and Society 40(12): 2614-2634.

50. Maurer M (2020) Nourishing Environments, Caring Cities: Gardening and the Social Reproduction of the Urban Environment in Deindustrial Michigan. City \& Society 32(3): 716-737.

51. United Cities and Local Governments Asia Pacific (2020) Seeds of Hope: Urban gardening as a food resiliency initiative during the covid-19 pandemic.

52. Imanishi I, Uchiyama J, Tsukui T, Hisatsuni J, Ide K, et al. (2019) Therapeutic Potential of an Endolysin Derived from Kayvirus S25-3 for Staphylococcal Impetigo. Viruses 11(9): 769.

53. Tang HHF, Lang A, Teo SM, Judd LM, Gangnon R, et al. (2021) Developmental patterns in the nasopharyngeal microbiome during infancy are associated with asthma risk. J Allergy Clin Immunol 147(5): 1683-1691.

54. Damiani G, Gironi LC, Kridin K, Pacifico A, Buja A, et al. (2021) Maskinduced Koebner phenomenon and its clinical phenotypes: A multicenter real-life study focusing on 873 dermatological consultations during COVID-19 pandemics. Dermatol Ther 34(2): e14823.

55. Prochnow D, Höing B, Kleiser R, Lindenberg R, Wittsack HJ, et al. (2013) The neural correlates of affect reading: an fMRI study on faces and gestures. Behav Brain Res 237:270-277.

56. Kemmerer D (2021) What modulates the Mirror Neuron System during action observation?: Multiple factors involving the action, the actor, the observer, the relationship between actor and observer, and the context. Prog Neurobiol 102128.

57. Zhang Y, Frassinelli D, Tuomainen J, Skipper JI, Vigliocco G, et al. (2021) More than words: word predictability, prosody, gesture and mouth movements in natural language comprehension. Proc Biol Sci 288(1955): 20210500.

58. Joffe AR (2021) COVID-19: Rethinking the Lockdown Groupthink. Front Public Health 9: 625778.

59. World Health Organization (2021) Noncommunicable diseases.

60. Magalhaes S, Pugliatti M, Riise T, Myhr K-M, Ciampi A, et al. (2019) Shedding light on the link between early life sun exposure and risk of 
multiple sclerosis: results from the EnvIMS Study. Int J Epidemiol 48(4) 1073-1082.

61. Lachenmeier DW (2008) Safety evaluation of topical applications of ethanol on the skin and inside the oral cavity. J Occup Med Toxicol 3: 26.

62. Langer S, Sedigh Salakdeh M, Goertz O, Steinau HU, Steinstraesser L, et al. (2004) The impact of topical antiseptics on skin microcirculation. Eur J Med Res 9(9): 449-454.

63. Morgan W (2020) Heavy use of hand sanitizer boosts antimicrobial resistance. Phys Org.

64. Gómez-Gallego C, Forsgren M, Selma-Royo M, Nermes M, Collado MC et al. (2012) The Composition and Diversity of the Gut Microbiota in Children Is Modifiable by the Household Dogs: Impact of a CanineSpecific Probiotic. Microorganisms. 9(3): 557.
65. Earls MR, Kinnevey PM, Brennan GI, Lazaris A, Skally M, et al. (2017) The recent emergence in hospitals of multidrug-resistant communityassociated sequence type 1 and spa type t127 methicillin-resistant Staphylococcus aureus investigated by whole-genome sequencing: Implications for screening. PLoS One 12(4): e0175542.

66. Gruber I, Heudorf U, Werner G, Pfeifer Y, Imirzalioglu C, et al. (2013) Multidrug-resistant bacteria in geriatric clinics, nursing homes, and ambulant care--prevalence and risk factors. Int J Med Microbiol 303(8): 405-409.

67. Silba N (2020) Michigan Bans Many Stores from Selling Seeds, Home Gardening Supplies, Calls Them "Not Necessary". Forbes. 